\title{
Expansion of traditional land-use and deforestation: a case study of an adat forest in the Kandilo Subwatershed, East Kalimantan, Indonesia
}

\author{
Hunggul Y. S. H. Nugroho ${ }^{1,2} \cdot$ Anne van der Veen ${ }^{1} \cdot$ Andrew K. Skidmore ${ }^{3}$. \\ Yousif A. Hussin ${ }^{3}$
}

Received: 27 June 2016/ Accepted: 7 February 2017/Published online: 24 June 2017

(c) The Author(s) 2017. This article is an open access publication

\begin{abstract}
Deforestation issues are more problematic when indigenous (adat) communities, living within a forest, have lived there for many generations. These adat communities, who employ traditional land-use, are frequently accused of encroaching on the forest. To understand existing and future trends in the spatial patterns of the expansion of traditional land-use and deforestation, we conducted a case study in the Kandilo Subwatershed using mixed methods with image interpretation, spatial modelling and sociocultural surveys to examine the interrelationships between physical conditions, community characteristics and traditional land-use expansion. We investigated community characteristics through household interviews, communication with key informants, and discussions with focus
\end{abstract}

Project funding: This study was financially supported with the cooperation between the Tropenbos International Indonesia Program and the Forestry Research and Development Agency of the Indonesian Ministry of Forestry.

The online version is available at http://www.springerlink.com

Corresponding editor: Tao $\mathrm{Xu}$.

Hunggul Y. S. H. Nugroho

hunggulys@yahoo.com; hunggulys@forda-mof.org

1 Department of PGM, Faculty of Geo-Information Science and Earth Observation, University of Twente, P.O. Box 217, 7500 AE Enschede, The Netherlands

2 Environment and Forestry Research and Development Institute of Macassar (BP2LHK Makassar), J1. Perintis Kemerdekaan Km. 16, 5 Sudiang, Makassar, Sulawesi Selatan, Indonesia

3 Department of Natural Resources, Faculty of GeoInformation Science and Earth Observation, University of Twente, P.O. Box 217, 7500 AE Enschede, The Netherlands groups. By using an area production model, we were able to analyze the effect of improved farming systems, policy intervention and law enforcement on traditional land-use expansion and deforestation. Based on our examination of a 20-year period of traditional land-use activities in adat forests, the evidence indicated that the steeper the slope of the land and the farther the distance from the village, the lower the rate of deforestation. Our study found that customary law, regulating traditional land-use, played an important role in controlling deforestation and land degradation. We conclude that the integration of land allocation, improved farming practices and enforcement of customary law are effective measures to improve traditional land productivity while avoiding deforestation and land degradation.

Keywords Adat people $\cdot$ Agriculture expansion - Area production model (APM) · Customary law · Deforestation · Traditional land-use

\section{Introduction}

Deforestation is defined as the conversion process of forested land to nonforested land (Blaser 2010; Boucher et al. 2011; Kementerian Kehutanan 2011). The most common causes of deforestation include resource privatization, fiscal incentives for land conversion, tenure policies, urbanization, resettlement development, and in tropical areas, the demand for agricultural land is the main driver (Adams et al. 2013; Akinyemi 2013; Barbier 2004; Boafo 2013; Chi et al. 2013; Foley et al. 2005; Palm et al. 2010; Shearman et al. 2009). According to the FAO (2011), during the period 2000-2010, the annual world rate of forest conversion to agricultural land was approximately 13 
million hectares. For the period 1990-2005, Indonesia was responsible for approximately 23\% (1.9 million ha/year) of deforestation worldwide (the highest deforestation rate in the world), and slowed to 0.68 million ha/year between 2005 and 2010 (FAO 2011).

Recent evidence shows that in areas with a high rate of deforestation, commercial farmers are the main agents of deforestation (Adams et al. 2013; Lininger 2011; Mertz 2009; Rudel et al. 2009; Seidenberg et al. 2003). In areas with low deforestation rates, however, small farmers and subsistence shifting cultivation are seen as the major contributors (Damnyag et al. 2013; Geist and Lambin 2002; Lininger 2011; Rudel et al. 2010; Shearman et al. 2009). The potential pressure of small farms on forests is high due to the millions of people who rely on agriculture for their livelihoods, dwelling in or near forest areas. In Indonesia, approximately 25,800 villages (36.7\% of all villages in Indonesia) are inside or adjacent to forest areas. Of these, 98\% rely on agriculture for their livelihoods (Badan Planologi Kehutanan 2007; Direktorat Jenderal Planologi Kehutanan 2009).

These issues are more problematic when indigenous people have lived inside the forest for many generations. In Indonesia, adat or customary land rights and customary systems of tenure have become a critical element of contention (Heryani and Grant 2004; Yasmi et al. 2010). Following the introduction of Forestry Law No. 41/1999, concerning the change in status from adat forest to state forest, adat communities living in these forests, who have done so for generations, have been accused of encroaching (Hartanto et al. 2008). In many parts of Indonesia, adat communities have been blamed for deforestation and forest destruction (Cahyadi 2014; IWGIA 2011; Wijaya 2014).

Traditionally, adat land-use is a system of shifting cultivation that incorporates long fallow periods based on indigenous knowledge and bound by customary laws. Based on their research, scientists believe that indigenous knowledge is a valuable source for maintaining a balance between natural resource conservation and farming activities (Chun 2014; Mulyoutami et al. 2009; Wangpakapattanawong et al. 2010). In this paper, we will test the hypothesis that managed forest based on customary law and indigenous wisdom will report lower rate of deforestation.

Previous studies from many countries show how improved productivity and policy interventions concerning land rights security have positive impacts on food security and deterring deforestation (Angelsen and Kaimowitz, 2001; Araujo et al. 2010; Branca et al. 2011; Chi et al. 2013; Epule et al. 2014; Fearnside 2001; Tachibana et al. 2001; Tomich et al. 2001). However, there are still knowledge gaps, especially in the relationships between and among the biophysical, economic development, sociocultural aspects, and effective policy responses (Carr 2008; Chomitz et al. 2007; Damnyag et al. 2013; Mattsson et al. 2012; Pasgaard 2013; Pouliot et al. 2012). Moreover, most studies of deforestation drivers have been based on macrolevel regional or national data, thus presenting difficulties in addressing the complexity of local situations (Bottazzi and Dao 2013).

The aim of this study was to generate an understanding of spatial patterns of existing and future trends in traditional land-use expansion and deforestation. We used image interpretation, spatial modelling and sociocultural surveys to examine interrelationships between and among the physical conditions, community characteristics and traditional land-use expansion. In this paper, traditional land-use refers to shifting agricultural systems with very low or no external inputs and low outputs (Gonzales Bernaldez 1991; Ochoa-Gaona 2001; Plieninger et al. 2006; Susana and Ochoa-Gaona 2011). Using an area production model (APM), we simulated the effect of improved traditional farming systems, policy intervention and law enforcement on traditional land-use expansion and deforestation.

\section{Materials and methods}

\section{Research area}

Kandilo Subwatershed (Fig. 1) is located in the Paser District in southeastern East Kalimantan Province, Indonesia, on the island of Borneo. The area covers 206,460 ha distributed over 17 villages of two subdistricts (Muara Komam and Batu Sopang). Its main river, the Kandilo (181 km), flows from the Mount Lumut Protection Forest $(1210 \mathrm{~m}$ a.s.l.) to the downstream flood plain in Tanah Grogot, the capital city of Paser District. The Kandilo River is the main water source for the lowland areas of Paser District. Approximately 96 million $\mathrm{m}^{3} /$ year of irrigation and domestic water, valued at US \$ 7.8 million per year, is provided by Mount Lumut Protection Forest (Tropenbos International Indonesia 2006).

Based on the analysis of the Designation of Provincial Forest Area and Inland Water, Coastal and Marine Ecosystems Map (Ministry of Forestry Decree No. 79/Kpts-II/2001), $22 \%$ of the Kandilo Subwatershed (46,250 ha) is a nonforest area (Area Penggunaan LainAPL) and $78 \%(160,210 \mathrm{ha})$ is forest zone: protection forest (Hutan Lindung-HL), production forest (Hutan Produksi-HP) and limited production forest (Hutan Produksi terbatas-HPT). Based on our analysis of land cover for 2012, forested land covered 160,914 ha. Agricultural land covered 30,090 ha, consisting of subsistence food crops $(27,147 \mathrm{ha})$, oil palm (1444 ha), and rubber 


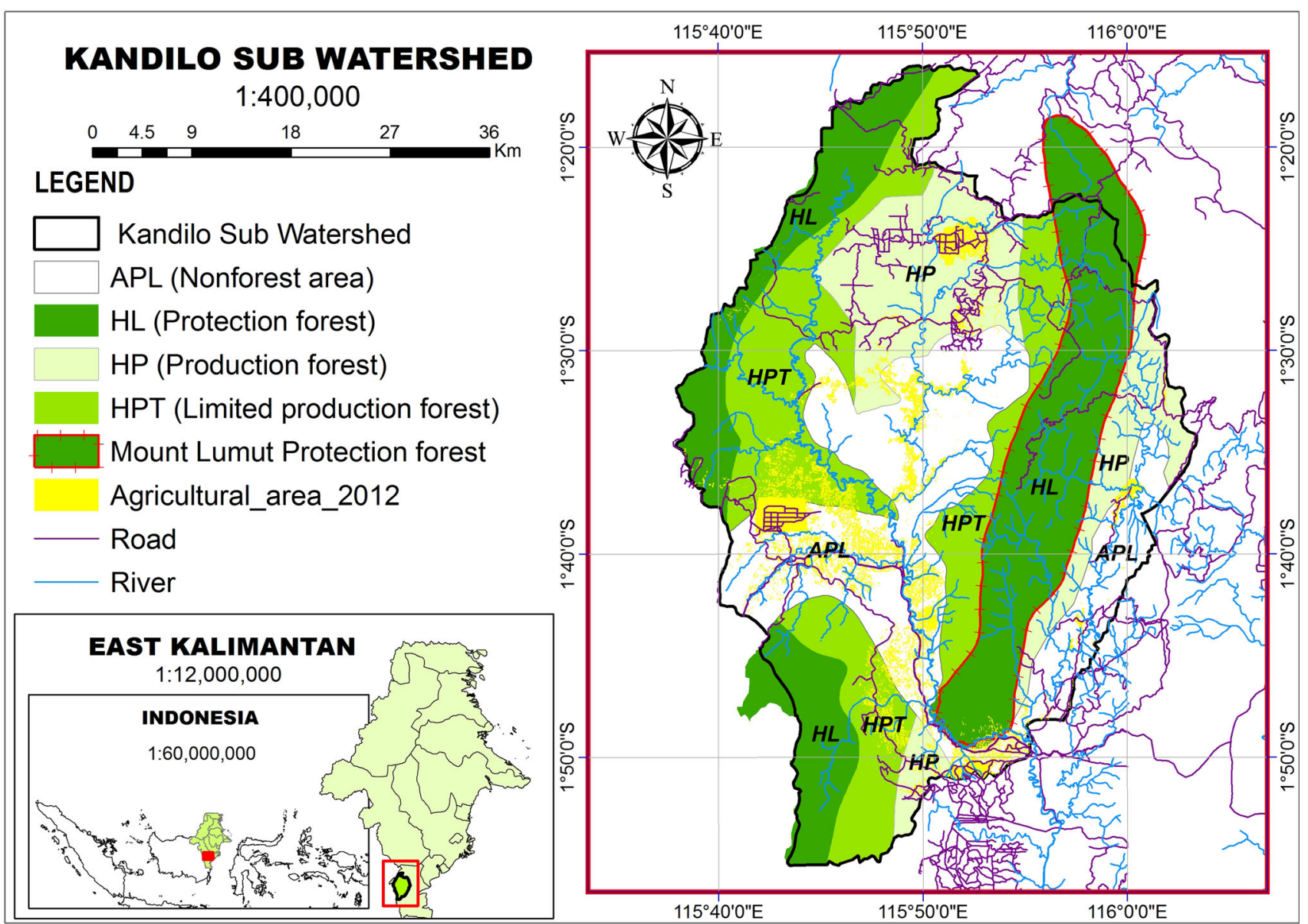

Fig. 1 Map of Kandilo Subwatershed

plantations (1449 ha); 34\% of the subsistence food crops, $17 \%$ of the oil palm, and $10 \%$ of the rubber plantation areas were situated in forest zones.

The people in the Kandilo Subwatershed represent three sociocultural backgrounds: (1) Paser indigenous people (Dayak Paser), (2) Banjar people, immigrants from South Kalimantan, and (3) migrants from outside Kalimantan, primarily from Java and Sulawesi through the central government Transmigration Program.

Subsistence farming with minimum inputs and outputs is the most common agricultural system in the study area. The immigrants originally practiced permanent farming systems of planting food crops (e.g., upland rice, soybeans, maize) and rubber. The adat communities cultivated primarily upland rice in shifting cultivation systems applying very low amounts of fertilizer, herbicides and other agrochemical inputs.

Traditionally, land parcels were 1-3 ha per parcel, constant from year to year. Upland rice was planted for two to three seasons (2-3 years) followed by an average of 10 years fallow. After 3 years, when soil fertility diminished, farmers moved to regenerated secondary forest, their previous fallowed sites, and cleared them using slash and burn methods.

The upland rice, oil palm, and rubber adat communities planted an annual average production of $0.6,3.6$ and 0.48 tons/ha respectively. This is low when compared to the annual district productivity levels of $2.9,14$, and 1.4 tons/ha in the same period (2010-2011) (BPS Kabupaten Pasir 2011). Based on a standard conversion from unhusked rice to husked rice (milling yield) in Indonesia, which is $62.7 \%$ (Suhari 2015), an average number of household members of five people and an average extent of cultivated land about 1 ha per household, rice production in the study area was estimated equal to $107 \mathrm{~kg}$ per capita per year. Minimum standard of living for rural people in Indonesia is equivalent to $132 \mathrm{~kg}$ of rice per capita per year (Ratnasari 2013), and the optimum standard of living (including sugar, fish, meat, clothes, housing, education) is equivalent to 1 ton of rice per capita per year (KLH 2009).

However, in the last decade, villagers in general in many parts of the world have started to change their farming methods from shifting to permanent cultivation (Hariyadi and Ticktin 2012; Heinimann et al. 2013; Mertz 2009). In 
response to better access to urban areas and changing prices, many farmers have started to cultivate permanent rubber or oil palm crops mixed with upland rice. After 3 years, when the rubber/oil palm canopies block the sun and upland rice cannot grow, they start to clear new land for another plantation of mixed crops. However, due to the presence of the rubber and oil palm, the farmers no longer return to a parcel of land after 15 years. After 3 years, they look for new land to cultivate. Without appropriate measures from both external and/or internal institutions, this uncontrolled system will lead to excessive deforestation.

\section{Data preparation}

We collected both spatial and nonspatial data. Our spatial data consisted of maps of land-use, designated forest, slope, rivers, roads, settlements, and adat forest. Satellite images with less than $10 \%$ cloud cover from 6 years (1992, 1996, 2000, 2006, 2009 and 2012) were analyzed using image processing software Ermapper 7.1 (Earth Resource Mapping, USA) and ArcGIS 10.1 (Esri, Redlands, CA, USA) to produce land-use and land cover maps based on the APM land-use classification.

Spatial APM differentiates land-use into three land categories: agricultural, forest, and other (Forest Science Division 2001). Each category is then divided into subcategories (agricultural land: subsistence food, local market and industrial crops; forest land: farm, industrial and environmental forests; other land: potential agricultural, potential forest and unproductive land).

For an accurate classification, several ground checks were conducted from 2009 to 2013. In this study, shifting agricultural systems with very low or no inputs were categorized as subsistence crops. Oil palm and rubber plantations were classified as market crops. Settlements, rivers, and lakes were classified as unproductive land.

Nonspatial data consisted of district and village level data. District level data covered population growth, gross domestic product/capita, agricultural and commodity productivity derived from a series of statistical data of Paser Regency from 2000 to 2012. Data at the village level was collected using surveys through informal dialogues with individuals, household interviews using questionnaires, interviews with key informants, focus group discussions, farmland/field visits and analysis of secondary data from annual unpublished village reports that provide basic data and information on the village from 2000 to 2012. For a better understanding of how sociocultural variables influence land-use change and deforestation, we observed three communities living in forest areas representing different cultures: (1) Muluy (adat community), (2) Rantau Layung and Rantau Buta (mixed adat and migrant community), and (3) Swan Slutung (migrant community). The three communities were visited periodically from 2009 to 2013 to observing daily activities, norms and beliefs through deep interviews, focus group discussions (FGDs) and informal meetings. Our hypothesis was that different cultures will have different opinions and preferences and will behave differently, which will affect deforestation differently.

To acquire more detailed information on specific issues, we conducted personal interviews with key respondents such as adat heads and elders.

Achieving accurate sociocultural data based on direct interviews was challenging since some respondents refrained from openly discussing their "considered-illegal" forest-based activities. To minimize misinformation and to anticipate some inconsistent responses, especially with regard to farming systems, forest-based income generation, implementation of customary law, and the extent and location of traditional land-use, we conducted a series of periodic field visits from 2009 to 2013 .

\section{Analysis of existing traditional land-use expansion}

By overlaying a series of land-use and land cover maps, we were able to calculate and locate traditional land-use expansion and forest conversion. In this study, upland rice, rubber and oil palm plantations cultivated by adat communities were classified as traditional land-use. The main output of this analysis process was a map of existing (observed) traditional land-use expansion from 1992 to 2012. By overlaying this map with maps of slope class, roads, rivers and villages, we were able to calculate the extent and density of traditional land-use expansion based on slope class, and distance from road, river and/or village. Further, the observed land-use change was used to validate the APM by comparing the observed to the predicted expansion (APM output) in the same period pixel by pixel.

\section{Modelling traditional land-use expansion and forest conversion}

Modelling is a simplification of reality to enhance understanding of the systems scientifically and to project future outcomes (Jakeman et al. 2009; Wätzold et al. 2006). In this study, we used APM, a simulation model of land-use changes (Hussin et al. 1995; Sandewall and Nilsson 2001; Xiao et al. 2001), to project traditional land-use expansion in the future as a response to exogenous variable changes: human population pressure, economic development, improved agricultural productivity and policy intervention. The APM was developed in 1982 by the FAO to numerically simulate land-use changes. In 1991, APM was connected to the Integrated Land and Water Information System (ILWIS), a raster-based geographic information 
system (GIS) by de Gier and Hussin to improve the spatial capacity of the model in predicting which areas would be the new land-use (Forest Science Division 2001; Hussin et al. 1995). On the basis of several uses at different sites, APM is considered an appropriate tool to model deforestation and forest degradation (Ato 1996; Hamzah 2012; Hussin et al. 1995; Sandewall and Nilsson 2001; Sawathvong 2004; Yanuariadi 1999).

The area production model runs on three assumptions: (1) the demand for subsistence crops depends only on population growth, (2) the demand for market crops and industrial/export crops is influenced by economic factors (GDP), and (3) production depends on productivity and the extent of the cultivated area (Forest Science Division 2001). These assumptions are in line with findings mentioned by several scholars. The correlation between agricultural land demand and deforestation is significantly affected by population pressure (Akinyemi 2013; Chi et al. 2013; Entwisle et al. 2008; Mertens et al. 2000; Pfeffer et al. 2005), accessibility (Entwisle et al. 2008; Lininger 2011; May-Tobin 2011; Purnamasari 2010), growth of income per capita, rising costs, price of agricultural products, and other macroeconomic factors (Barbier, 2004; Gaveau et al. 2009; Mertens et al. 2000).

There are two steps to predict future deforestation. The first step is to calculate agricultural demand using numerical APM, and the second step is to predict spatial deforestation using spatial APM.

The demand for new land for agriculture was calculated using the following formula (Forest Science Division 2001)

$$
\begin{aligned}
N_{\mathbf{A g}}= & {\left[C_{\mathbf{S}}\left(i P o p / i A g_{\mathbf{S}}\right)^{n}\right]+\left[C_{\mathbf{M}}\left(i G D P / i A g_{\mathbf{M}}\right)^{n}\right] } \\
& +\left[C_{\mathbf{I}}\left(i G D P / i A g_{\mathbf{I n}}\right)^{n}\right],
\end{aligned}
$$

where $N_{\mathbf{A g}}$ is the projected area of agricultural land, $n$ is the number of simulation years, $N$ is the new area needed, $C$ is the current area, iPop is the growth factor of population, Pop is the population, $\mathrm{iAg}_{\mathrm{s}}$ is the growth factor of subsistence crop productivity, $\mathrm{iAg}_{\mathrm{M}}$ is the growth factor of market crop productivity, $\mathrm{iAg}_{\mathrm{In}}$ is the growth factor of industrial crop productivity, $\mathrm{i} G D P$ is the growth factor of gross domestic product.

The total demand for agricultural lands resulting from the numerical APM will be written in the ILWIS script as an input for a spatial APM to predict spatial/locational distribution of new agricultural land. When demand is positive, there will be land-use conversion from nonagricultural land (forest and shrub). Spatial APM assumes that land-use conversion starts from the periphery of existing agricultural land and converted to forestland or other land according to a friction value and the distance to an agricultural area. In general, when demand for agricultural land increases, land transfer from another class is generated in a certain priority order (Hussin et al. 1995; Sawathvong 2004; Yanuariadi 1999). The general framework of the spatial APM is presented in Fig. 2.

The growth factors for this simulation are presented in Table 1. Growth of population, GDP and agricultural productivity in the Paser District were analyzed from statistical data for the Paser District. Productivity growth at the village level was derived from our village surveys.

\section{Analysis of the factor map}

We found four factors that influenced deforestation susceptibility: distance to village, distance to roads, distance to rivers, and slope. The APM assumes a positive relationship between the distance from villages to forests and land conversion; moreover, the steeper the slope, the slower the land conversion. Each factor was analyzed separately to identify its significance in affecting land-use conversion. Then each factor was crossed with the observed land-use conversion in order to calculate the density value for each factor. Density values were calculated as a percentage of the converted area for each factor.

\section{Model validation}

Validation was conducted by overlaying predicted land-use conversion maps with observed land-use conversion maps for the same periods. Due to data availability (population, GDP, and agriculture production), the APM validation was run for the period 2000-2012. For spatial validation, we compared the predicted and observed maps pixel by pixel. The number of overlapping pixels of the two maps represents the accuracy of APM in projecting locations of land-use conversion.

\section{Scenario development and model simulation}

Scenario development refers to the creative process to define the pathways of exogenous variables for particular systems to deal with future complexities and uncertainties (Verburg et al. 2006; Wollenberg et al. 2000).

We conducted model simulations to project the impacts of exogenous variables (population pressure, economic development, improved farming practices and policy intervention) on the future state of traditional land use and deforestation.

The simulation period was 25 years (2012-2037) applying the following sets of assumptions: (1) Population growth was projected to simulate population pressure. (2) GDP growth was projected to simulate economic development. (3) Increased agriculture productivity was projected to simulate improved farming practices. (4) The order of priority of land-use transfer was changed to simulate policy interventions and law enforcement. 
Fig. 2 Framework of Spatial APM

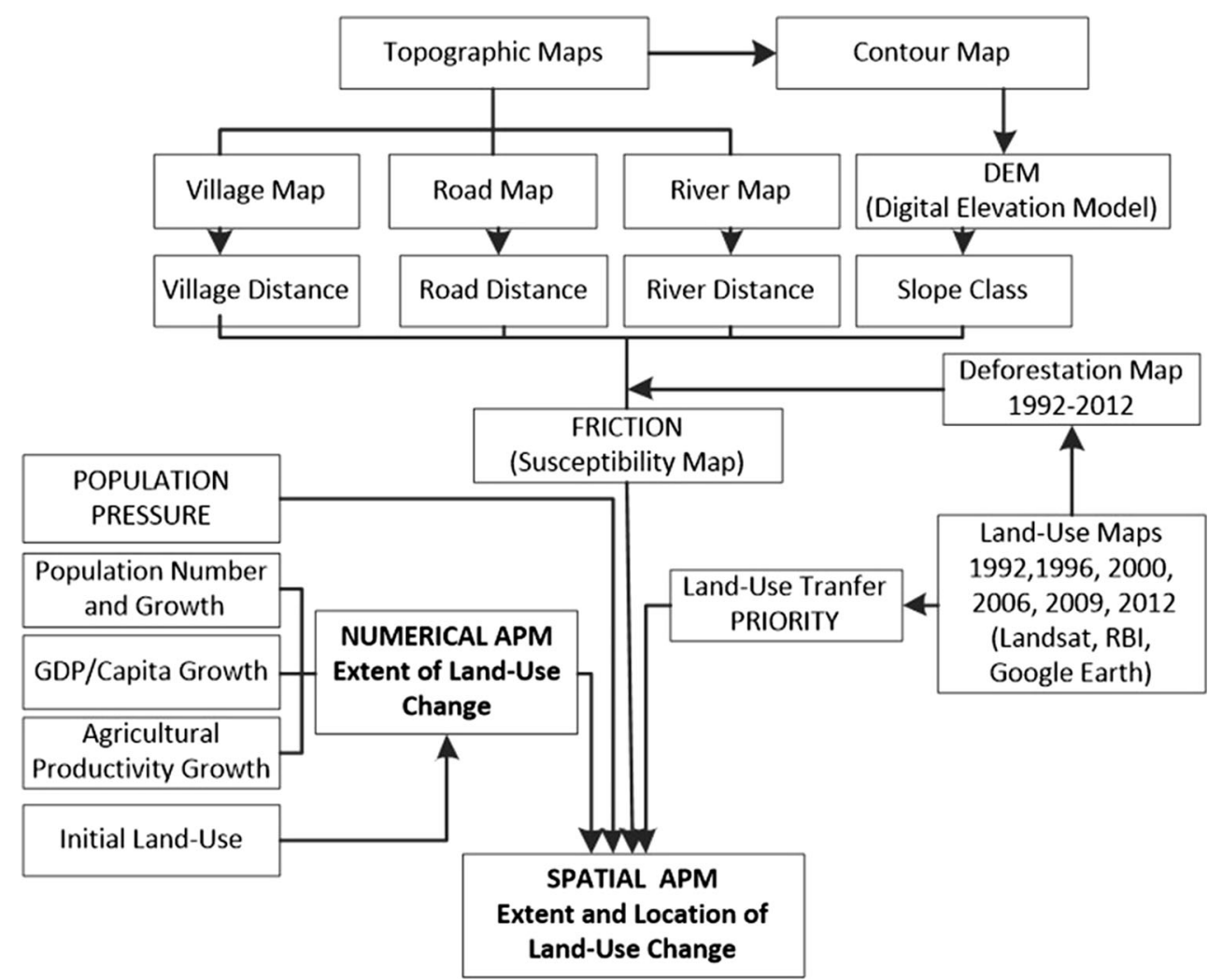

Table 1 Growth factors for the period 2000-2012

\begin{tabular}{|c|c|c|c|c|c|c|c|c|c|}
\hline \multirow[t]{3}{*}{ Year } & \multirow{2}{*}{\multicolumn{2}{|c|}{ Population growth }} & \multirow{3}{*}{$\begin{array}{l}\text { GDP growth } \\
\text { District }\end{array}$} & \multicolumn{6}{|c|}{ Growth of crop productivity/increase in crop productivity } \\
\hline & & & & $\begin{array}{l}\text { Subsiste } \\
\text { (upland }\end{array}$ & crops & $\begin{array}{l}\text { Market } \\
\text { (oil paln }\end{array}$ & & $\begin{array}{l}\text { Market } \\
\text { (rubber) }\end{array}$ & \\
\hline & District & Villages & & District & Villages & District & Villages & District & Villages \\
\hline 2000-2006 & $1.027^{\mathrm{a}}$ & 1.020 & 1.079 & 1.039 & $0.78^{\mathrm{b}}$ & 1.072 & 1.001 & 1.003 & 0.985 \\
\hline 2006-2012 & 1.053 & 1.029 & 1.092 & 1.014 & 0.76 & 1.024 & 1.018 & 1.001 & 0.985 \\
\hline
\end{tabular}

a 1.027 means $2.7 \%$ growth

b 0.78 means $22 \%$ decline

The challenge in developing scenarios, however, was to produce realistic values for input variables. In this study, input variables at the village level were projected based on our survey findings. Concurrently, regional level variables (population and GDP growth) were synchronized with projections by the National and Regional Planning Agency (BAPPEDA Kalimantan Timur 2008; BAPPENAS 2005).

Based on actual data and information generated from our village surveys, we developed three scenarios: an unexpected, an expected, and a visionary outcome. The first considers unexpected situations to reflect the negative that the existing situation could deteriorate. The second scenario estimates the most likely outcomes driven by existing trends of exogenous factors, a business-as-usual scenario. The third scenario reflects our vision about future livelihood security, land tenure certainty, and synergizing adat law (hukum adat) and formal law.

\section{Scenario 1: unexpected outcomes}

Under the unexpected outcome scenario, the population will increase constantly at the previous growth rate until the second period and then ascend. In the existing situation, there is illegal immigration of people looking for land as a result of new road developments passing through the forest area. Conversely, the young people from forest villages move to peri-urban and urban areas in search of off-farm employment and will leave their land unmanaged. We assume that this phenomenon will persist until the second period. In this scenario, productivity of food crops is 
constant as a result of limited labor, good quality seed and fertilizer. Meanwhile, industrial crop productivity (oil palm and rubber plantations) will start to increase slowly in the fourth period. In terms of economic development, the GDP per capita will increase following the trend in agricultural sectors at the provincial level, but will slow down in the third period. We assume that there is no significant new policy concerning forest management throughout the duration of the scenarios. In the existing situation, the regional forestry office conducts insufficient forest monitoring and law enforcement due to limited authority and budget. Local institutions, wisdom, norms and values of the adat communities are slowly being eroded by consumerism and short-term economic considerations. For the APM in this situation, we have given the same priority to all landuse types in terms of land-use conversion. At the same time, agricultural land will expand taking over all other types of land. Slope and accessibility are the only factors determining which area will be converted first. The growth factors for Scenario 1 are presented in Table 2.

\section{Scenario 2: expected outcomes, business as usual}

Under the scenario of business as usual, the population growth is constant in forest villages and increase in villages outside forests after the second period following the growth trend at the provincial level (BAPPENAS 2005). Better prospects of on-farm income trigger people from other area to migrate into slightly sloped areas in the forest periphery. Productivity of food and market crops in forest villages is constant until 2025 but will then increase. Meanwhile, in the villages outside forests, we assume that the Ministry of Agriculture Regional Office will introduce new technologies and deliver better production inputs to farmers. In terms of economic development, the GDP per capita will increase following the trend in agricultural sectors at the provincial level (BAPPEDA Kalimantan Timur 2008). In this scenario, we assume that the Ministry of Forestry Regional Offices will start to enforce the law. But due to limited authority and resources, these efforts will only focus on protection forests close to roads and villages. In our spatial APM, the scenario of such policy interventions will be executed by setting a certain priority order of land- use conversion. The conversion of protection forest will not start until all land in the higher priority classes has been converted. The growth factors for Scenario 2 are presented in Table 3.

\section{Scenario 3: visionary outcome}

Under this scenario, population growth in all villages will increase after the second period following population growth rates at the district level. The GDP per capita will increase following the trend in the agricultural sector, especially for oil palm and rubber. We assume that the central government will enact new regulations concerning forest boundaries. Disturbed production forests in areas with slopes under $40 \%$ will be excluded from state forests and handed over to indigenous communities (Fig. 3). In this policy scheme, adat communities will have legal tenure to manage their land.

Under Scenario 3, according to the proposed regulations, several villages will be situated in nonforest areas. As a result, villagers who formerly utilized forestland using subsistence farming methods, will improve their farming systems due to tenure security by applying better technology and production inputs to increase productivity. The regional offices (Ministry of Agriculture) will introduce better farming techniques and deliver better production inputs (fertilizer, seedlings) to farmers living outside forest areas.

Under Scenario 3, formal laws will be enforced consistently in line with adat law implementation. Protection forest will only be utilized by indigenous people in limited areas, under strict monitoring and with no disturbance to the environment. This includes restrictions on the use of the riparian buffer zone $100 \mathrm{~m}$ to the left and right of the riverbank and forestland with slopes above $40 \%$.

In this scenario, we assume that customary rights and adat institutions will consistently regulate the daily activities of the adat people. In restricted areas, based on customary law, farming activities will not be allowed. In the APM, implementation of policy intervention and revitalization of adat rule are simulated by reclassifying land-use codes and resetting the order of priority from low to high: nonforest areas, production forest, limited production forest
Table 2 Growth factors in Scenario 1

\begin{tabular}{lllllll}
\hline Period & Year & Population growth & GDP growth & \multicolumn{3}{l}{ Crops productivity growth } \\
\cline { 5 - 7 } & & & & Upland rice & Oil palm & rubber \\
\hline 1 & $2012-2017$ & 1.0300 & 1.092 & 1.0000 & 1.0010 & 1.0010 \\
2 & $2018-2022$ & 1.0300 & 1.092 & 1.0000 & 1.0010 & 1.0010 \\
3 & $2023-2027$ & 1.0600 & 1.092 & 1.0000 & 1.0100 & 1.0100 \\
4 & $2028-2032$ & 1.0800 & 1.092 & 1.0000 & 1.0100 & 1.0100 \\
5 & $2033-2037$ & 1.0800 & 1.092 & 1.0000 & 1.0160 & 1.0160 \\
\hline
\end{tabular}


Table 3 Growth factors in Scenario 2

\begin{tabular}{lllllll}
\hline Period & Year & Population growth & GDP growth & \multicolumn{3}{l}{ Crops productivity growth } \\
\cline { 5 - 7 } & & & & Upland rice & Oil palm & Rubber \\
\hline 1 & $2012-2017$ & 1.0200 & 1.0920 & 1.0000 & 1.0010 & 1.0010 \\
2 & $2018-2022$ & 1.0200 & 1.0920 & 1.0000 & 1.0100 & 1.0100 \\
3 & $2023-2027$ & 1.0500 & 1.0920 & 1.0000 & 1.0200 & 1.0200 \\
4 & $2028-2032$ & 1.0600 & 1.0920 & 1.0000 & 1.0400 & 1.0400 \\
5 & $2033-2037$ & 1.0600 & 1.0920 & 1.0000 & 1.0600 & 1.0400 \\
\hline
\end{tabular}

\section{FOREST ALTERATION SCENARIO}

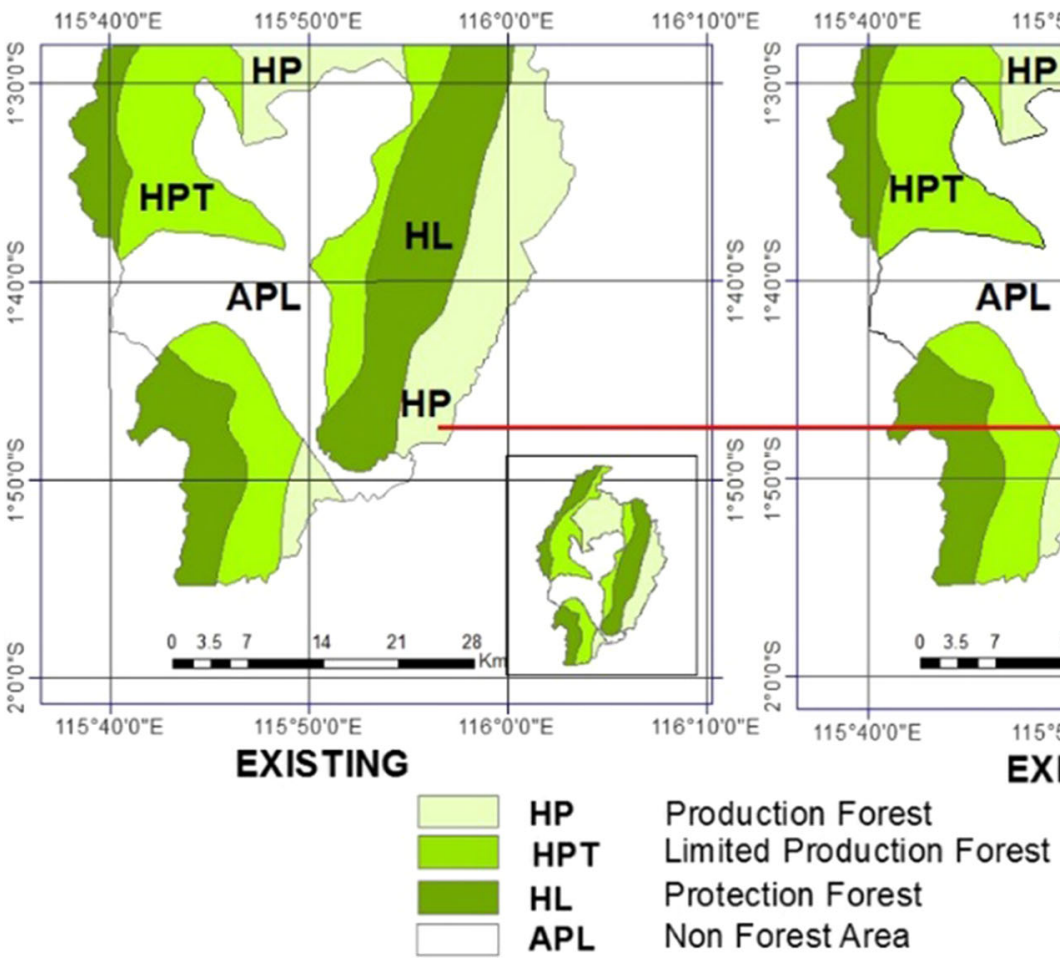

Fig. 3 Forest zone alteration in Scenario 3

and protection forest. In this order, deforestation in protection forests will not start before production forests are deforested/converted to another use. The riparian buffer zone and sloping areas above $40 \%$ were classified as unproductive land and were given a value of 0 (zero) in the priority order. By having 0 value, the areas will not be converted to agriculture land. The growth factors for Scenario 3 are presented in Table 4.

\section{Results}

\section{Traditional land-use expansion for the period 1992-2012}

The land-use and cover changes from 1992 to 2012 are illustrated in Figs. 4 and 5. Figure 4 shows the spatial distribution of traditional land-use expansion, and Fig. 5 shows trends in each land-use change. From 1992 to 2012, forest cover decreased from 185,957 to 175,515 ha at a rate of $0.29 \%$ per year. Shrub increased from 12,605 to 14,664 ha at a rate of $0.74 \%$ per year and traditional farming increased from 6412 to 30,090 ha at a rate of $8.1 \%$ per year.

In contrast to the trend in agriculture, which consistently increases, the trend in both forest and shrub cover shows an alternating increase and decrease every fourth and sixth year (Fig. 5). This finding reflects a sequence process of forest recovery from abandoned agricultural land returning to shrub and from shrub to secondary forest as a characteristic of a traditional shifting agricultural system. In the ninth and tenth years after being abandoned and covered by secondary forest, the land is again reopened. These results are consistent with the results of our social surveys and 
Table 4 Growth factors in Scenario 3

\begin{tabular}{lllllll}
\hline Period & Year & Population growth & GDP growth & \multicolumn{3}{l}{ Crops productivity growth } \\
\cline { 5 - 7 } & & & & Upland rice & Oil palm & Rubber \\
\hline 1 & $2012-2017$ & 1.030 & 1.100 & 1.020 & 1.020 & 1.000 \\
2 & $2018-2022$ & 1.025 & 1.110 & 1.020 & 1.040 & 1.040 \\
3 & $2023-2027$ & 1.020 & 1.130 & 1.050 & 1.040 & 1.040 \\
4 & $2028-2032$ & 1.060 & 1.140 & 1.050 & 1.060 & 1.080 \\
5 & $2033-2037$ & 1.060 & 1.150 & 1.050 & 1.060 & 1.080 \\
\hline
\end{tabular}

interviews with farmers in which the average fallow period is 10 years.

The resulting factor map analysis shows that traditional land-use expansion occurs mainly on slightly sloped areas. In the period $2000-2012$, the majority $(80 \%)$ of land-use conversion was located on slopes under $10 \%, 17 \%$ on slopes of $10-25 \%$ and only $3 \%$ on slopes above $25 \%$.

Traditional land-use expansion generally starts from villages and the periphery of agricultural areas. The agricultural lands were located $0-8 \mathrm{~km}$ from the villages. Fiftyfive percent were concentrated between 1 and $3 \mathrm{~km}$, and $25 \%$ were located between 3 and $5 \mathrm{~km}$ (Fig. 6). However, few locations were situated far from the village and the agricultural periphery.

With respect to distance to the main road, $87 \%$ of new traditional land-use was located less than $1 \mathrm{~km}$, and $12 \%$ occurred between 1 and $2 \mathrm{~km}$. There was no agricultural activity farther than $4 \mathrm{~km}$ from the river; $67 \%$ was located within a radius of less than $1 \mathrm{~km}$.

In terms of correlation between deforestation rate and cultural background, Table 5 shows the location and distribution of deforestation and deforestation per capita per year in three sampled communities with different cultural backgrounds.

In Table 5, deforestation per capita in Muluy is lower than in the other two villages. The Muluy people (indigenous Dayak Paser) are more reluctant to adopt new farming systems, which require more labor, time, and production inputs than traditional systems do. In general, Muluy people grow annual upland rice on a single parcel for 3 years and then abandon the land for 10-15 years. Deforestation is lower in Muluy than in Rantau Layung and Rantau Buta, due to the strict adat regulations governing their farming activities and gathering of forest products. Meanwhile, people from Java and Sulawesi living in Swan Slutung have more experience in intensified farming than do the indigenous and local migrants from Kalimantan. On the other hand, Rantau Buta and Rantau Layung, consisting of the Banjar people and indigenous Dayak Paser, have started planting permanent crops such as rubber and oil palm. The Banjar people have more financial capital, knowledge and experience. These results support our hypothesis that different cultures will have different strategies and behaviors. Yet, the migrant and indigenous communities do exchange knowledge about farming systems.

Figure 7 shows a map of forest designation and traditional-land use areas of the adat forests of Muluy and Rantau Layung. The adat communities divide adat forests into several functions using their own language: Strat (area designated for houses and other facilities), Alas adat and Alas Tuo (restricted forest areas forbidden for swidden activities), Alas Nareng and Alas Burok (reserved forest areas for agricultural activities), Awa Pengeramu (communal forest for fruit trees and wood), Awa Ngumo and Awa Penyekulo (areas designated for agricultural activities to produce staple foods). In Fig. 7, we can see that in general, adat systems designate land in line with the Ministry of Forestry.

From interpretations of the adat map (Fig. 7) supported by series of field visits, we conclude that in general, adat people have a sustainable system for utilizing their forests. In Rantau Layung Forest, awa ngumo, awa penyekulo, and awa pengeramu forests are situated in gentle-sloped production forests. Alas adat and alas nareng are situated in protection forests and steep-sloped production forests. Cultivated areas from 1992 to 2012 were consistently located in Awa Ngumo and Awa Penyekulo, areas designated for agriculture (Fig. 7). Likewise, in Muluy Forest in the middle of the Mount Lumut Protection Forest, people have been conducting subsistence shifting cultivation for years, but only in limited areas close to roads and rivers. However, since 2010, with the boom in oil palm cultivation in the Paser District, a few people have started to expand their agriculture land by opening alas adat/alas tuo forest close to the new main road.

\section{Projected traditional land-use expansion and deforestation}

To determine the level of confidence in our APM for representing measured experimental data, we validated our numerical and spatial APM. Numerical APM accuracy was determined by comparing the extent of the predicted with the observed traditional land-use expansion for the period 2000 to 2012. 
Fig. 4 Spatial distribution of traditional land-use expansion from 1992 to 2012
TRADITIONAL LAND-USE EXPANSION 1992 - 2012

$1: 1,000,000$

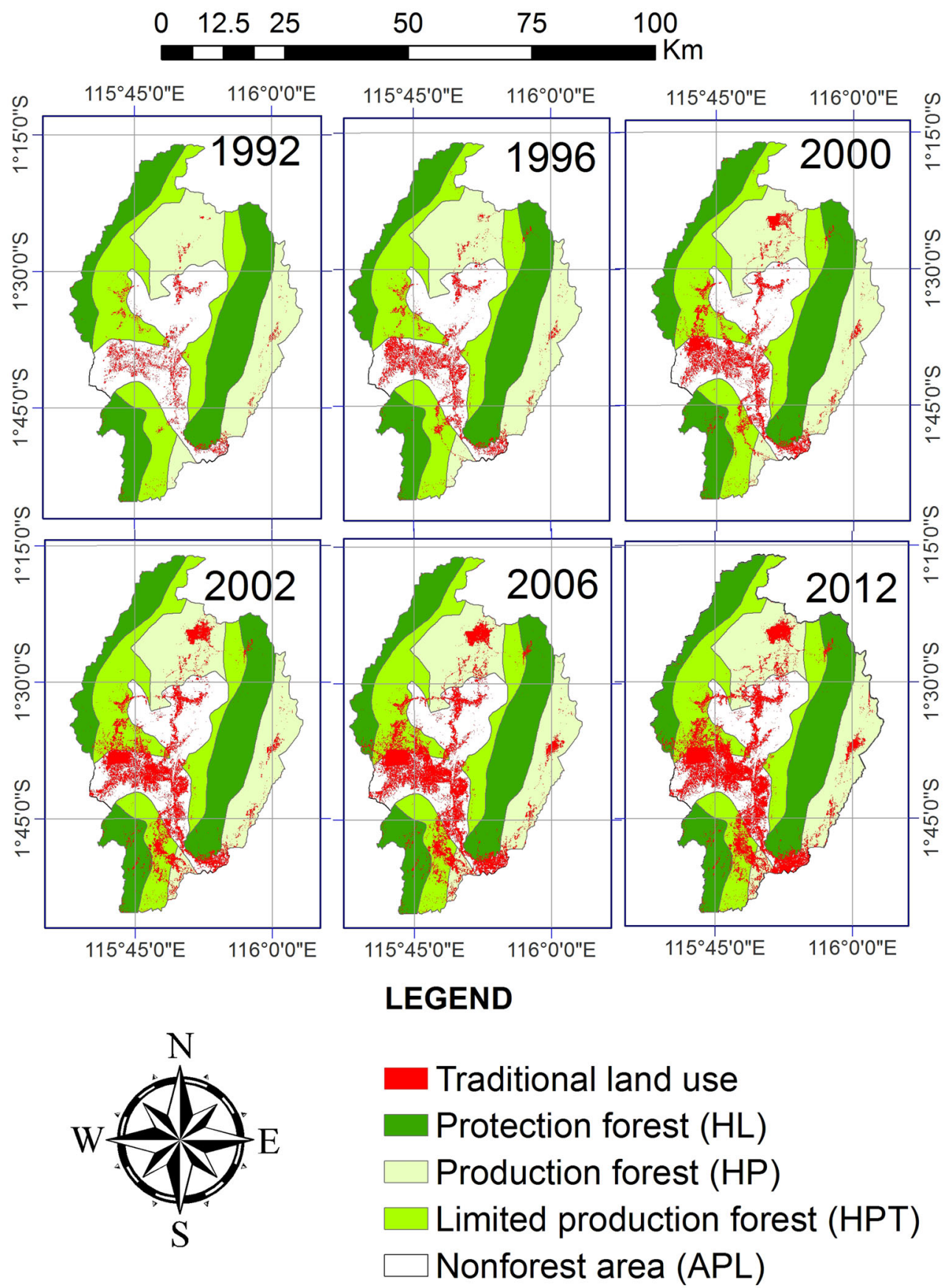

agricultural area into agricultural area for the period 2000-2012. Using the spatial APM and pixel-by-pixel analysis, we found that $67 \%$ of the observed expansion of traditional land-use into non-agricultural area was accurately predicted. The other $33 \%$ could not be predicted (unpredicted). The result of the validation assessment of the APM is presented in Table 6. 


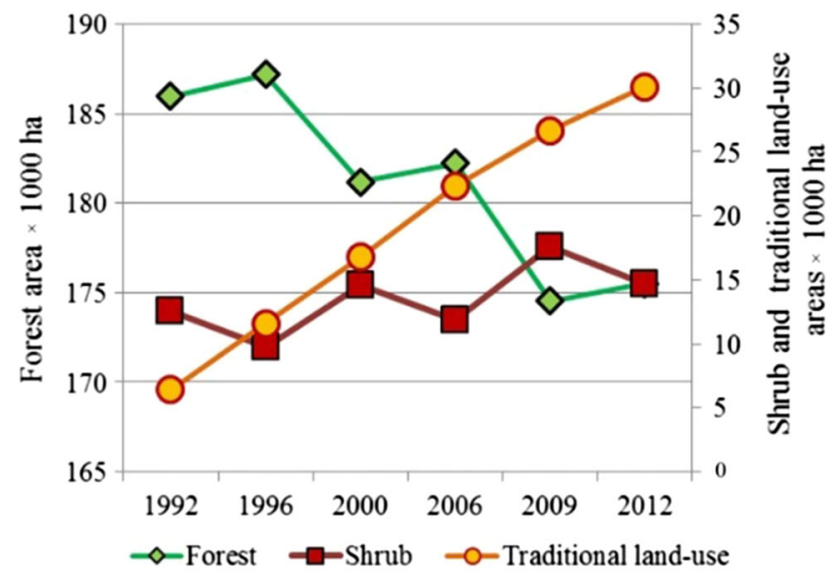

Fig. 5 Trends in land cover and land-use change from 1992 to 2012

\section{Traditional land-use projection}

We identified critical elements in the development of our scenarios. Villagers in general were trapped in subsistence farming systems, with low inputs and outputs. They were unable to afford the cost of better farming inputs. Considered as encroachers, there was no farming input subsidy from the regional government such as seed, fertilizer and technology for people living inside the forest. Relying only on the natural fertility of the land, production of upland rice decreased by almost half for the second consecutive year. As a consequence, when productivity decreased in the second and third year, farmers sought new areas to cultivate. In general, their main concerns in deciding which particular locations to cultivate were distance from village, slope and accessibility. Relating regional government absenteeism to low productivity underlies the assumption of crop productivity in scenarios 1 and 2. Based on interviews, planting upland rice has been part of the local culture. Farmers will always plant upland rice using shifting cultivation although they have enough money to buy rice from the local market as found in previous studies in other areas (Hariyadi and Ticktin 2012). Shifting cultivation is not only an activity for producing food, but also part of the culture for maintaining a relationship among and between the community and nature.

The results of our 25-year projection are presented in Tables 7, 8 and 9 and Fig. 9. For the BAU scenario, traditional land-use will expand by $201 \%$ in 25 years at a rate of $1.4 \%$ per year. Thirty six percent of the new land will be situated in forest areas, mainly in permanent production and limited production forest.

In the sustainable scenario, due to improved farming systems, forestry law enforcement synergized with the revitalization of adat law and enactment of the forest alteration policy, the model predicts that traditional landuse in 2037 will have expanded by 53\%, with $10 \%$ of that new land in forest areas. In this scenario, the 2012 productivity of upland rice, rubber and oil palm will triple.

To map spatial distribution of land-use conversion and to calculate deforestation, we overlaid the spatial output of APM onto the Designation of Provincial Forest Area and Inland

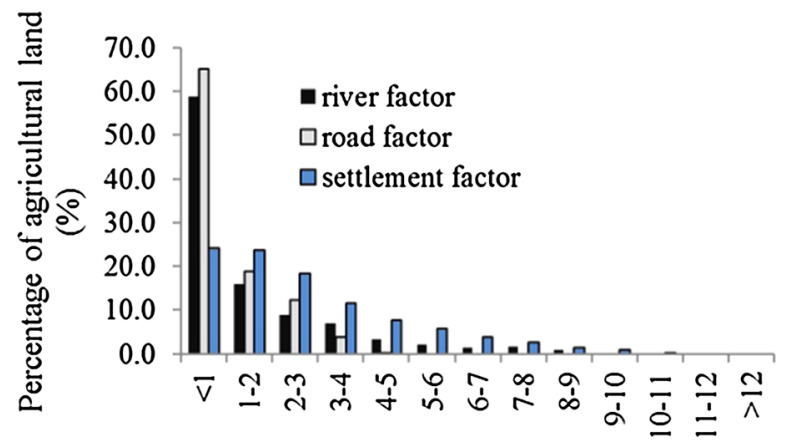

Distance in $\mathrm{Km}$

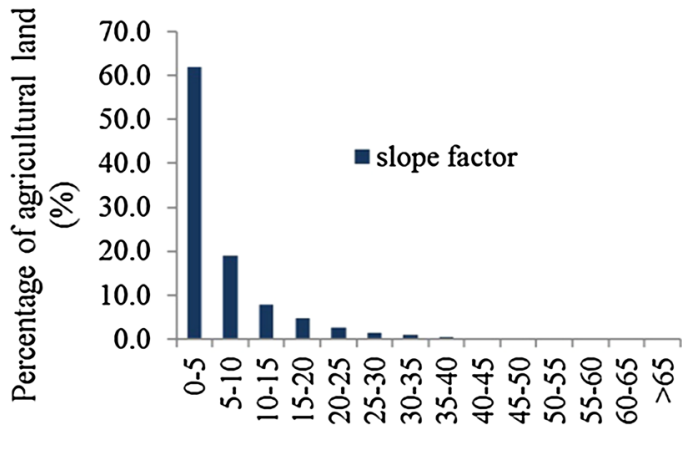

Slope in percent

Fig. 6 Distribution of traditional expansion based on slope of land and distance to the river, the road, and the settlement

Table 5 Deforestation per capita/year in three communities with different cultural backgrounds

\begin{tabular}{lcccc}
\hline Communities & 20 years deforestation (ha) & Population & Deforestation (ha) per capita/year & Forest designation \\
\hline Rantau Buta-Rantau Layung & 940 & 343 & 0.14 & Production forest \\
Swan Slutung & 1556 & 651 & 0.12 & Production forest \\
Muluy & 128 & 128 & 0.05 & Protection forest \\
Total & 2624 & 1122 & 0.12 & \\
\hline
\end{tabular}


Fig. 7 Map of Adat forest of Muluy and Rantau Layung

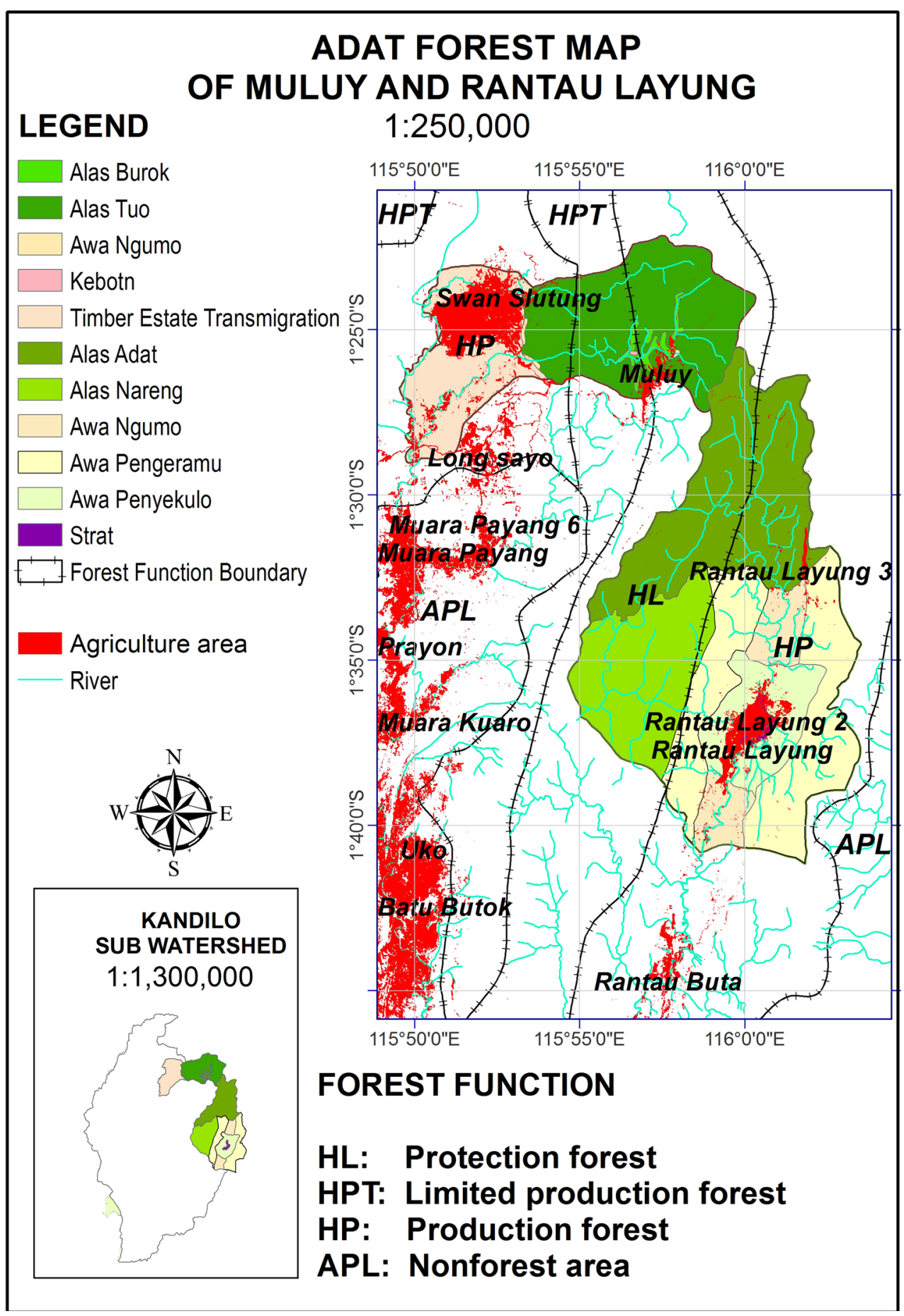

Water, Coastal and Marine Ecosystem of East Kalimantan Province Map. This map divides East Kalimantan Land into 4 designated areas: HPT, HP, HL, and APL. The spatial distribution of future agricultural expansion is presented in Fig. 9.

In Fig. 9, we can see that in scenario 1 (unexpected) and scenario 2 (expected/BAU), traditional land-use expanded to all land-use in almost similar proportion. In contrast, scenario 3 (visionary) directed the majority of the traditional land-use expansion to the nonforest area. The distribution of traditional land-use based on forest designation of the three scenarios is presented in Table 9.

\section{Discussion}

The engagement of adat communities in the sustainable forest management of Indonesia has proven to be reliable. Three scenarios were used to further test the reliability of 
Fig. 8 Spatial distribution of the predictions for land-use conversion

Table 6 Validation assessment of APM
VALIDATION MAP

1:300,000

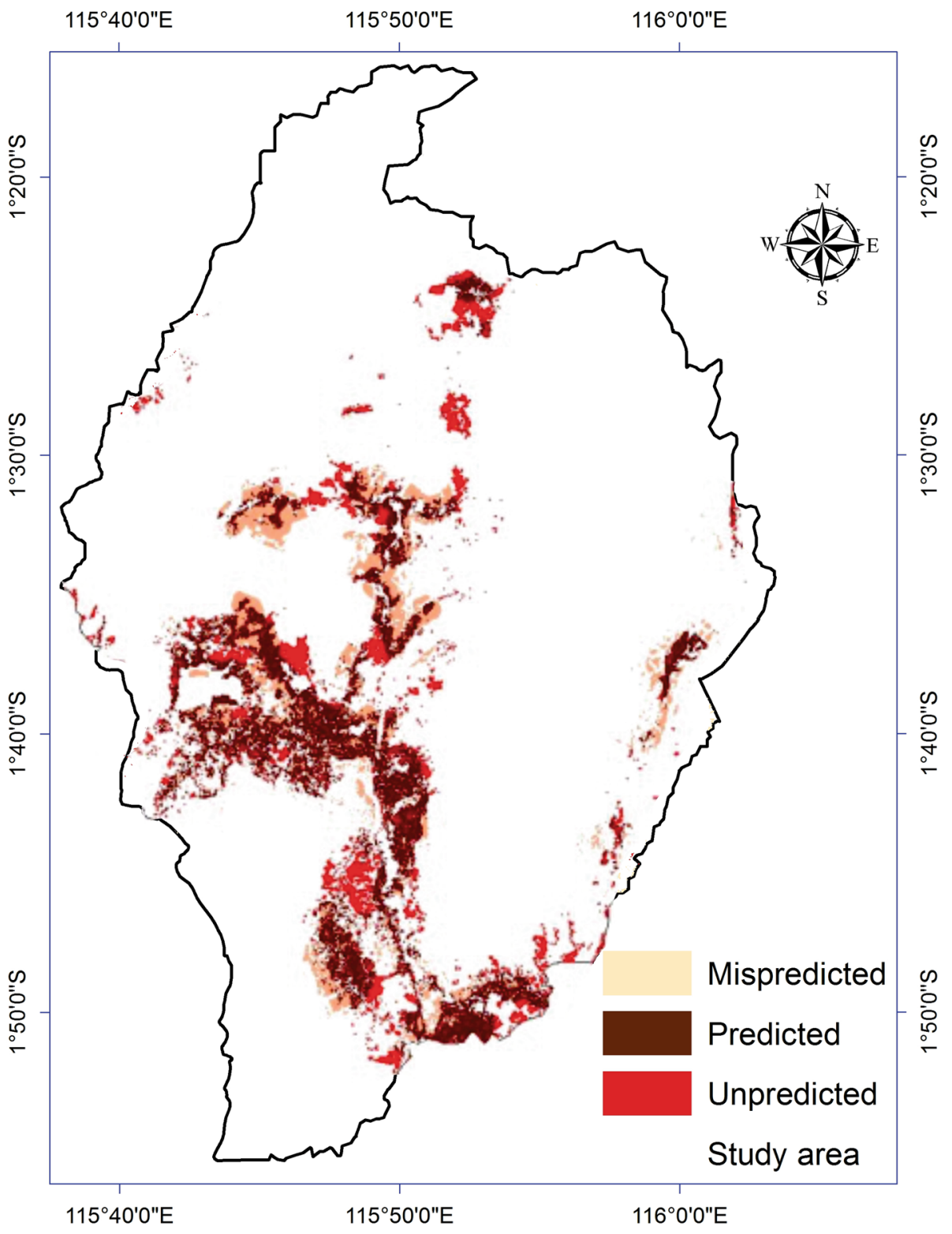

\begin{tabular}{lrc}
\hline Category & Area (ha) & Validity (\%) \\
\hline Observed agriculture area for 2012 based on map analysis & 30,090 & \\
Predicted agriculture area for 2012 using numerical APM & 29,169 & 96 \\
Observed land-use conversion based on map analysis & 9170 & \\
Predicted land-use conversion using spatial APM & 10,555 & \\
Location accurately predicted & 6192 & 67 \\
Unpredicted & 2979 & 33 \\
\hline
\end{tabular}


Table 7 Agricultural productivity in 2037

\begin{tabular}{|c|c|c|c|c|c|c|}
\hline \multirow[t]{2}{*}{ Scenarios } & \multicolumn{2}{|l|}{ Food crops } & \multicolumn{2}{|l|}{ Oil palm } & \multicolumn{2}{|l|}{ Rubber } \\
\hline & Productivity (tons/ha) & Increase $(\%)$ & Productivity (tons/ha) & Increase $(\%)$ & Productivity (tons/ha) & Increase $(\%)$ \\
\hline Existing & 0.6 & & 3.6 & & 0.48 & \\
\hline (1) Unexpected & 0.6 & 0 & 4.35 & 21 & 0.58 & 21 \\
\hline (2) Expected/BAU & 0.6 & 0 & 6.84 & 90 & 0.85 & 77 \\
\hline (3) Visionary & 1.52 & 153 & 10.54 & 193 & 1.53 & 219 \\
\hline
\end{tabular}

Table 8 Agricultural area in 2037

\begin{tabular}{|c|c|c|c|c|c|c|c|c|}
\hline \multirow[t]{2}{*}{ Scenarios } & \multicolumn{2}{|c|}{ Food crops } & \multicolumn{2}{|l|}{ Oil palm } & \multicolumn{2}{|l|}{ Rubber } & \multicolumn{2}{|l|}{ Total } \\
\hline & Area (ha) & Increase $(\%)$ & Area (ha) & Increase $(\%)$ & Area (ha) & Increase $(\%)$ & Area (ha) & Increase $(\%)$ \\
\hline Existing & 27,147 & & 1444 & & 1449 & & 30,090 & \\
\hline (1) Unexpected & 106,241 & 291 & 9892 & 585 & 10,829 & 647 & 126,962 & 322 \\
\hline (2) Expected/BAU & 76,631 & 182 & 6349 & 340 & 7577 & 423 & 90,557 & 201 \\
\hline (3) Visionary & 28,343 & 4 & 8950 & 520 & 8780 & 506 & 46,073 & 53 \\
\hline
\end{tabular}

Table 9 Projected traditional land-use expansion and deforestation

\begin{tabular}{|c|c|c|c|c|c|c|c|c|c|}
\hline \multirow[t]{3}{*}{ Forest designation $^{a}$} & \multirow[t]{3}{*}{ Existing forest (ha) } & \multicolumn{8}{|c|}{ Traditional land-use (ha) } \\
\hline & & \multicolumn{2}{|c|}{ Baseline } & \multicolumn{2}{|c|}{ Scenario 1} & \multicolumn{2}{|c|}{ Scenario 2} & \multicolumn{2}{|c|}{ Scenario 3} \\
\hline & & 2012 & Def. $(\%)$ & 2037 & Def. $(\%)$ & 2037 & Def. $(\%)$ & 2037 & Def. (\%) \\
\hline HPT & 50,657 & 6175 & -12.2 & 26,889 & -53.1 & 19,249 & -38.0 & 8306 & -16.4 \\
\hline HP & 49,549 & 5764 & -11.6 & 42,963 & -86.7 & 32,605 & -65.8 & 6868 & -13.9 \\
\hline HL & 60,708 & 1563 & -2.6 & 20,598 & -33.9 & 7422 & -12.2 & 2059 & -3.4 \\
\hline APL & 45,546 & 16,588 & -36.4 & 36,512 & -80.2 & 31,281 & -68.7 & 28,840 & -63.3 \\
\hline Forest & 160,914 & 13,502 & -8.4 & 90,450 & -56.2 & 59,276 & -36.8 & 17,233 & -10.7 \\
\hline Total & 206,460 & 30,090 & -14.6 & 126,962 & -61.5 & 90,557 & -43.9 & 46,073 & -22.3 \\
\hline
\end{tabular}

${ }^{a}$ HPT: limited production forest; HP: production forest, HL: protection forest; APL: nonforest area; Def: deforestation

such engagement. These scenarios (unexpected, expected, and visionary outcomes) emphasize our expectations of future livelihood security, land tenure certainty, and synergizing adat law and formal law.

The spatial analysis shows that traditional land-use expansion increases as slope and distance to villages, roads, and rivers decreases (Fig. 6). This same pattern is common; farmers first clear flat areas, close to water sources or roads and then move to steeper slopes farther from roads (Avoided Deforestation Partners 2009; Kinnaird et al. 2003; Lambin and Meyfroidt 2010; OchoaGaona 2001; Ochoa-Gaona and González-Espinosa 2000).

However, our data from the factor map analysis support statements that land-use change and forest transition patterns are dynamic (Lambin and Meyfroidt 2010); people's actual behaviors are not always associated with "intentions" and "attitudes" (Holdershaw and Gendall 2008; Lu 1999). Only $2-5 \%$ of the traditional land-use was situated on steep slopes, far from villages, agricultural peripheries, roads and rivers.

This potential for unpredictable behaviour is reflected in the results of our APM validation (Fig. 8; Table 6); 33\% of observed land-use conversion could not be predicted due to their limited relevance of slope and distance factors. However, in terms of accuracy of location, the use of spatial APM in this study was better than the study in Phrao, which reached 53\% (Ato 1996) and in Kutai Barat, which reached 65\% (Hamzah 2012). 

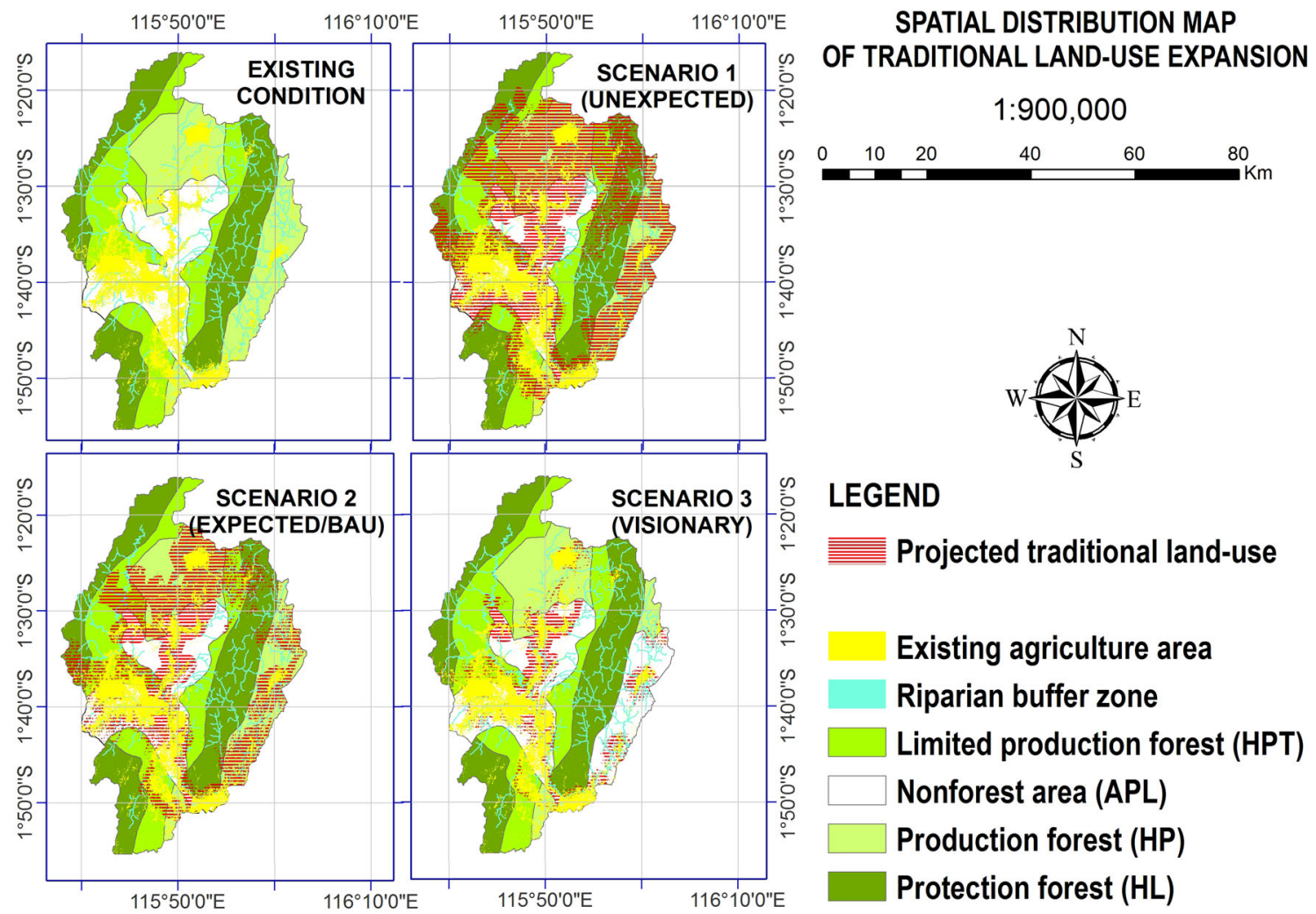

LEGEND

\section{Projected traditional land-use}

\section{Existing agriculture area}

Riparian buffer zone

Limited production forest (HPT)

Nonforest area (APL)

Production forest (HP)

Protection forest (HL)

Fig. 9 Spatial distribution of agricultural expansion for three different scenarios

Our spatial analysis of three villages showed that sociocultural characteristics, experiences, and farming systems (Table 5) can affect deforestation per capita. The lowest deforestation per capita occurred in Muluy communities, in line with the study of (Chi et al. 2013) who mentioned that cultural characteristics of communities are one of the most important factors affecting land-use conversion. Norms, beliefs and traditions are tightly linked to the ways indigenous people manage their forest resources (Mulyoutami et al. 2009; Sasaoka and Laumonier 2012). In the village dominated by adat people, adat regulations and beliefs concerning the best time to start land clearing, plugging and planting, which areas and trees are forbidden to cut, and how large an area can be utilized per household per planting season are still followed. The adat law has governed adat forest management for many generations by regulating people's rights of access to forest products, the designation of forestland cleared for agriculture, and the planting or protection of trees in the forest (Butt 2014).

Traditionally, the period of cultivation ends when the soil fertility is exhausted and productivity decreases. Instead of intensifying inputs to raise production, farmers expand their land into forest areas. In forest areas, agriculture cannot be intensified and thus ensure food security and income generation (Brown and Schreckenberg 1998; Grogan et al. 2013).
For decision-makers, the essential task, however, is how to develop new policies enabling traditional communities to meet their basic needs for an adequate standard of living (such as for sugar, fish, meat, clothes, housing, education), which is equivalent to 1 ton/capita/year of rice without damaging the environment. For villagers whose livelihoods depend on agriculture, the minimum for farm production per household is equivalent to 7.9 tons of upland rice per year.

In the visionary scenario, farming systems are improved in line with consistent law enforcement, synergizing formal law regulating general prohibition and adat law regulating daily based norms and activities. Based on our observations of the cultivation areas of the adat communities from 1992 to 2012 (Fig. 7), we came to understand that adat people have managed their forest in line with adat law.

In the visionary scenario, certain forest areas with slopes under $40 \%$ are given to indigenous communities together with the revitalization of customary rights and adat institutions. As a result, in the final year, productivity of food and market crops will increase by 180 and $200 \%$, respectively, compared with the initial year (Table 7). Even though rice production is still lower than the district level, it will be sufficient to provide a minimum standard of living. After forest conversion, there is a possibility that villagers could legally have $3-4$ ha of land. One hectare for 
upland rice and 2-3 ha for rubber would be sufficient to provide enough rice for household needs and other food for the whole year. By having more land with secure tenure, local people would be able to improve their farming systems. Two village areas would be excluded from the forest zone starting with the third period. Since both villages will no longer be situated in the forest zone, the regional government will be able to officially support them to improve farming production inputs and technology. However, in Indonesia, communal rights to land are among the most intriguing of concepts (Bakker 2008). In some cases, communal ownership can be subject to forest degradation when local institutions are managed inappropriately (Perez-Verdin et al. 2009). In such a scenario, deforestation can occur, but to a lesser extent compared with the initial deforestation rate, which would be $10.7 \%$ over a 25 -year period (Table 9) at a rate of $0.4 \%$ per year.

\section{Conclusions}

This paper discusses spatial patterns of traditional land-use expansion and deforestation and how physical aspects as well as socioculture and policy affect their dynamics. The evidence indicates that slope and accessibility are important factors affecting traditional land-use expansion. The steeper the slope and the farther the distance, the lower the rate of deforestation. However, due to the dynamics of human behavior, some areas of traditional land-use are randomly located, inconsistent with these factors.

The results of the village surveys support our hypotheses concerning the sociocultural aspects of deforestation. Our spatial analysis of three villages shows differences between sociocultural characteristics, experience, and farming practices. The lowest rate of deforestation per capita occurred where customary laws strictly regulate people's activities. Meanwhile, in the more modern communities, deforestation was higher as a consequence of higher financial capital as well as knowledge and experience. Analyzing adat forest designation maps and 20 years of traditional farming practices of the adat people, we reached the conclusion that adat people manage their forest sustainably. In general, there were similarities between land designated under adat law and that under the Ministry of Forestry. The adherence of adat law is a key reason that deforestation was controlled.

Since shifting cultivation has been part of adat culture for many generations, the solution is not to force them to convert to permanent agricultural systems. Rather, ensuring the security of land rights and assisting in the improvement of their shifting cultivation while moving toward more productive systems, with longer fallows, and providing better farming inputs and technology to maintain soil fertility. In fact, traditional land-use systems are feasible systems when physical constraints make modernization of agriculture impossible (Plieninger et al. 2006).

The essential measures, however, are empowerment of customary law and adaptation of indigenous knowledge in forest management to meet current needs and conditions. Long-term security and short-term consumption of agricultural commodities should be optimized through the combination of land management and local institutional enforcement. Land-use management that enhances farming income while avoiding deforestation and degradation must be promoted, supported by land allocation and implementation of formal laws that respect adat law and revitalize adat institutions.

Based on our projections, at least three factors decrease deforestation and increase community welfare: (1) improvement of farming practices, (2) land allocation to ensure livelihood security, and (3) law enforcement synergizing formal law and adat law to ensure implementation of sustainable land-use management. A combination of the three approaches will result in an increase in crop productivity, sufficient for households to have a minimum standard of living with less deforestation. However, to determine the reliability of our conclusions, further studies and more replication in other locations are needed.

Finally, instead of developing approaches to stop deforestation, this study explored spatial analytical approaches to provide a better understanding of deforestation in correlation with agricultural expansion. The accuracy of all projections may be subject to question. Different resolutions of spatial data as well as nonspatial data may produce different results. However, by combining spatial models with GIS and field surveys to develop scenarios that are as realistic as possible, we can provide better evidence to help decision-makers and other stakeholders design what strategies to prevent the projected outcomes.

Acknowledgements We thank the people of Muluy, Rantau Buta, Rantau Layung, and Swan Sutung for their support during our fieldwork.

Open Access This article is distributed under the terms of the Creative Commons Attribution 4.0 International License (http://crea tivecommons.org/licenses/by/4.0/), which permits unrestricted use, distribution, and reproduction in any medium, provided you give appropriate credit to the original author(s) and the source, provide a link to the Creative Commons license, and indicate if changes were made.

\section{References}

Adams C, Chamlian Munari L, Vliet N, Sereni Murrieta R, Piperata B, Futemma C, Spressola-Prado V (2013) Diversifying incomes and losing landscape complexity in Quilombola shifting 
cultivation communities of the atlantic rainforest (Brazil). Hum Ecol 41(1):119-137. doi:10.1007/s10745-012-9529-9

Akinyemi FO (2013) An assessment of land-use change in the Cocoa Belt of south-west Nigeria. Int J Remote Sens 34(8):2858-2875. doi:10.1080/01431161.2012.753167

Angelsen A, Kaimowitz D (2001) Agricultural technology and forests: a recapitulation Agricultural technologies and tropical deforestation. CABI Publishing, Wallingford, pp 383-402

Araujo C, Bonjean CA, Combes JL, Motel PC, Reis EJ (2010) Does land tenure insecurity drive deforestation in the Brazilian Amazon? CERDI, Etudes et Documents (vol E 2010.13): CERDI

Ato VA (1996) Prediction of deforestation using area production model (Master Thesis), International Institute of Aerospace Survey and Earth Science (ITC), Enschede, The Netherlands

Avoided Deforestation Partners (2009) REDD methodological module "Location and quantification of the threat of unplanned baseline deforestation" version 1.0, April 2009. Avoided Deforestation Partners.org

Badan Planologi Kehutanan (2007) Identifikasi Desa Dalam Kawasan Hutan 2007. Kerjasama Pusat Rencana dan Statistik Kehutanan, Departemen Kehutanan dengan Direktorat Statistik Pertanian, Badan Pusat Statistik, Jakarta

Bakker L (2008) "Can We Get Hak Ulayat?": land and community in Pasir and Nunukan, East Kalimantan. Center for Southeast Asia Studies. Center for Southeast Asia Studies, UC Berkeley. Retrieved from: http://escholarship.org/uc/item/5pj3z2jr

BAPPEDA Kalimantan Timur (2008) Rencana Pembangunan Jangka Panjang Daerah Propinsi Kalimantan Timur 2008. BAPPEDA Kalimantan Timur, Samarinda

BAPPENAS (2005) Proyeksi Pertumbuhan Penduduk Indonesia 2000-2025. Jakarta: Badan Perencanaan Pembangunan Nasional, Badan Pusat Statistik, dan United Nation Population Fund

Barbier EB (2004) Explaining agricultural land expansion and deforestation in developing countries. Am $\mathrm{J}$ Agric Econ 86(5):1347-1353. doi:10.1111/j.0002-9092.2004.00688.x

Blaser J (2010) Forest law compliance and governance in tropical countries: a region-by-region assessment of the status of forest law compliance and governance in the tropics, and recommendations for improvement. FAO and ITTO

Boafo J (2013) The impact of deforestation on forest livelihoods in Ghana. Backgrounder Africaportal. http://www.africaportal.org/ sites/default/files/Africa\%20Portal\%20Backgrounder\%20No.\% 2049.pdf. Cited 24 Agustus 2014

Bottazzi P, Dao H (2013) On the road through the Bolivian Amazon: a multi-level land governance analysis of deforestation. Land Use Policy 30(1):137-146. doi:10.1016/j.landusepol.2012.03. 010

Boucher D, Elias P, Lininger K, May-Tobin C, Roquemore S, Saxon E (2011) The root of the problem: what's driving tropical deforestation today?. Tropical Forest and Climate Initiative, Union of Concerned Scientists, Cambridge

BPS Kabupaten Pasir (2011) Kabupaten Pasir Dalam Angka 2011. Badan Pusat Statistik Kabupaten Pasir, Tanah Grogot

Branca G, McCarthy N, Lipper L, Jolejole MC (2011) Climate-smart agriculture: a synthesis of empirical evidence of food security and mitigation benefits from improved cropland management Mitigation of Climate Change in Agriculture Series 3. Food and Agriculture Organization of the United Nations, Rome

Brown D, Schreckenberg K (1998) Shifting cultivators as agents of deforestation: assessing the evidence. Nat Resour Perspect 29:1-14

Butt S (2014) Traditional land rights before the Indonesian Constitutional Court. LEAD J 10(1):59-73

Cahyadi F (2014) Indigenous people as victim of law on the prevention and eradication of forest destruction. http://www. aman.or.id/en/2014/11/21/indigenous-people-as-victim-of-law-on-
on-the-prevention-and-eradication-of-forest-destruction/Cited. 15 Jan 2015

Carr D (2008) Farm households and land use in a core conservation zone of the Maya Biosphere Reserve, Guatemala. Hum Ecol 36(2):231-248. doi:10.1007/s10745-007-9154-1

Chi V, Rompaey A, Govers G, Vanacker V, Schmook B, Hieu N (2013) Land transitions in Northwest Vietnam: an integrated analysis of biophysical and socio-cultural factors. Hum Ecol 41(1):37-50. doi:10.1007/s10745-013-9569-9

Chomitz KM, Buys Piet, De Luca Giacomo, Thomas TS, WertzKanounnikoff S (2007) At loggerheads? Agricultural expansion, poverty reduction, and environment in the tropical forests. A World Bank Policy Research Report. The World Bank, Washington, DC

Chun J (2014) A legal approach to induce the traditional knowledge of forest resources. For Policy Econ 38:40-45. doi:10.1016/j. forpol.2012.07.006

Damnyag L, Saastamoinen O, Blay D, Dwomoh FK, Anglaaere LCN, Pappinen A (2013) Sustaining protected areas: identifying and controlling deforestation and forest degradation drivers in the Ankasa Conservation Area, Ghana. Biol Conserv 165:86-94. doi:10.1016/j.biocon.2013.05.024

Direktorat Jenderal Planologi Kehutanan (2009) Identifikasi Desa Dalam Kawasan Hutan 2009. Kerjasama Departemen Kehutanan dengan Badan Pusat Statistik, Jakarta

Entwisle B, Rindfuss RR, Walsh SJ, Page PH (2008) Population growth and its spatial distribution as factors in the deforestation of Nang Rong, Thailand. Geoforum 39(2):879-897. doi:10.1016/ j.geoforum.2006.09.008

Epule ET, Peng C, Lepage L, Chen Z (2014) Policy options towards deforestation reduction in Cameroon: an analysis based on a systematic approach. Land Use Policy 36:405-415. doi:10.1016/ j.landusepol.2013.09.004

FAO (2011) The state of the world's land and water resources for food and agriculture (SOLAW) - managing systems at risk. Summary Report. Rome and Earthscan, London. Food and Agriculture Organization of the United Nations

Fearnside PM (2001) Land-tenure issues as factors in environmental destruction in Brazilian Amazonia: the case of Southern Pará. World Dev 29(8):1361-1372. doi:10.1016/S0305-750X(01)00039-0

Foley JA, DeFries R, Asner GP, Barford C, Bonan G, Carpenter SR, Chapin FS, Coe MT, Daily GC, Gibbs HK, Helkowski JH, Holloway T, Howard EA, Kucharik CJ, Monfreda C, Patz JA, Prentice IC, Ramankutty N, Snyder PK (2005) Global consequences of land use. Science 309(5734):570-574. doi:10.1126/ science. 1111772

Forest Science Division (2001) The area production model (APM) in numerical and spatial context: case studies and exercises. Forest Science Division, International Institute for Aerospace Survey and Earth Science, Enschede

Gaveau DLA, Linkie M, Suyadi Levang P, Leader-Williams N (2009) Three decades of deforestation in southwest Sumatra: effects of coffee prices, law enforcement and rural poverty. Biol Cons 142(3):597-605. doi:10.1016/j.biocon.2008.11.024

Geist HJ, Lambin EF (2002) Proximate causes and underlying driving forces of tropical deforestation: tropical forests are disappearing as the result of many pressures, both local and regional, acting in various combinations in different geographical locations. Bioscience 52(2):143-150. doi:10.1641/0006-3568(2002)052[0143: PCAUDF]2.0.CO;2

Gonzales Bernaldez F (1991) Ecological consequences of the abandonment of traditional land use systems in central Spain. In: Baudry J, Bunce RGH (eds) Land abandonment and its role in conservation. CIHEAM, Zaragoza, pp 23-29

Grogan K, Birch-Thomsen T, Lyimo J (2013) Transition of shifting cultivation and its impact on people's livelihoods in the Miombo 
Woodlands of Northern Zambia and South-Western Tanzania. Hum Ecol 41(1):77-92. doi:10.1007/s10745-012-9537-9

Hamzah H (2012) Modeling of tropical forest conversion to oil palm expansion using area production model: a case study of Nyuatan watershed. University of Twente Faculty of Geo-Information and Earth Observation (ITC), Enschede

Hariyadi B, Ticktin T (2012) From shifting cultivation to Cinnamon agroforestry: changing agricultural practices among the Serampas in the Kerinci Seblat National Park, Indonesia. Hum Ecol 40(2):315-325. doi:10.1007/s10745-012-9481-8

Hartanto H, Rangan H, Thorburn C, Kull C (2008) Strategic engagement and dynamic adaptation: customary forest management in Keribci, Central Sumatra, Indonesia. Paper presented at the 12th Biennial Conference of the International Association for the Study of Commons, England

Heinimann A, Hett C, Hurni K, Messerli P, Epprecht M, Jorgensen L, Breu T (2013) Socio-economic perspectives on shifting cultivation landscapes in Northern Laos. Hum Ecol 41(1):51-62. doi:10.1007/s10745-013-9564-1

Heryani E, Grant C (2004) Land administration in Indonesia. Paper presented at the 3rd FIG regional conference, Jakarta, Indonesia

Holdershaw J, Gendall P (2008, 9-11 July 2008) Understanding and predicting human behaviour. Paper presented at the ANZCA08: communication conference: power \& place, Wellington, New Zealand

Hussin YA, Bode J, Gier AD (1995) The crystal globe: a GIS-based operational area production model. Paper presented at the 16th Asian conference on remote sensing, Suranaree University of Technology, Nakhon Ratchasima, Thailand

IWGIA (2011) Update 2011-Indonesia. The Indigenous Worl$\mathrm{d}>$ Asia. http://www.iwgia.org/regions/asia/indonesia/43-engregions/asia/871-update-2011-indonesia. Cited 31 March 2015

Jakeman T, Chen S, Newham L, Pollino C (2009) Modelling and Adaptive Environmental Management. In: Allan C, Stankey G (eds) Adaptive environmental management. Springer, Dordrecht, pp 173-187

Kementerian Kehutanan (2011) Statistik Kehutanan 2010. Kementerian Kehutanan, Jakarta

Kinnaird MF, Sanderson EW, O'Brien TG, Wibisono HT, Woolmer G (2003) Deforestation trends in a tropical landscape and implications for endangered large mammals Tendencias de Deforestación en un Paisaje Tropical y Sus Implicancias para Mamíferos Grandes en Peligro. Conserv Biol 17(1):245-257. doi:10.1046/j.1523-1739.2003.02040.x

Lambin EF, Meyfroidt P (2010) Land use transitions: socio-ecological feedback versus socio-economic change. Land Use Policy 27(2):108-118. doi:10.1016/j.landusepol.2009.09.003

Lininger K (2011) Small-scale farming and shifting cultivation. In: Boucher D, Elias P, Lininger K, May-Tobin C, Roquemore S, Saxon E (eds) The root of the problem what's driving tropical deforestation today?. Union of Concerned Scientists, Cambridge, pp 89-94

Lu M (1999) Do people move when they say they will? Inconsistencies in individual migration behavior. Popul Environ 20(5):467-488. doi:10.1023/a:1023365119874

Mattsson E, Persson UM, Ostwald M, Nissanka SP (2012) REDD + readiness implications for Sri Lanka in terms of reducing deforestation. J Environ Manag 100:29-40. doi:10. 1016/j.jenvman.2012.01.018

May-Tobin C (2011) Small-scale farming and shifting cultivation. The root of the problem: What's driving tropical deforestation today? Tropical Forest and Climate Initiative, Union of Concerned Scientists, Cambridge, pp 89-94

Mertens B, Sunderlin WD, Ndoye O, Lambin EF (2000) Impact of macroeconomic change on deforestation in South Cameroon: integration of household survey and remotely-sensed data. World Dev 28(6):983-999

Mertz O (2009) Trends in shifting cultivation and the REDD mechanism. Curr Opin Environ Sustain 1(2):156-160. doi:10. 1016/j.cosust.2009.10.002

Mulyoutami E, Rismawan R, Joshi L (2009) Local knowledge and management of simpukng (forest gardens) among the Dayak people in East Kalimantan, Indonesia. For Ecol Manag 257(10):2054-2061. doi:10.1016/j.foreco.2009.01.042

Ochoa-Gaona S (2001) Traditional land-use systems and patterns of forest fragmentation in the highlands of Chiapas, Mexico. Environ Manag 27(4):571-586. doi:10.1007/s002670010171

Ochoa-Gaona S, González-Espinosa M (2000) Land use and deforestation in the highlands of Chiapas, Mexico. Appl Geogr 20(1):17-42. doi:10.1016/S0143-6228(99)00017-X

Palm CA, Smukler SM, Sullivan CC, Mutuo PK, Nyadzi GI, Walsh MG (2010) Identifying potential synergies and trade-offs for meeting food security and climate change objectives in subSaharan Africa. Proc Natl Acad Sci. doi:10.1073/pnas. 0912248107

Pasgaard M (2013) The challenge of assessing social dimensions of avoided deforestation: examples from Cambodia. Environ Impact Assess Rev 38:64-72. doi:10.1016/j.eiar.2012.06.002

Pedoman Penentuan Daya Dukung Lingkungan Hidup dalam Penataan Ruang Wilayah, Permen No. 17 Tahun 2009 Stat (2009)

Perez-Verdin G, Kim YS, Hospodarsky D, Tecle A (2009) Factors driving deforestation in common-pool resources in northern Mexico. J Environ Manag 90(1):331-340. doi:10.1016/j.jenv man.2007.10.001

Pfeffer MJ, Schlelhas JW, DeGloria SD, Gomez J (2005) Population, conservation, and land use change in Honduras. Agr Ecosyst Environ 110(1-2):14-28. doi:10.1016/j.agee.2005.05.003

Plieninger T, Höchtl F, Spek T (2006) Traditional land-use and nature conservation in European rural landscapes. Environ Sci Policy 9(4):317-321. doi:10.1016/j.envsci.2006.03.001

Pouliot M, Treue T, Obiri BD, Ouedraogo B (2012) Deforestation and the limited contribution of forests to rural livelihoods in West Africa: evidence from Burkina Faso and Ghana. Ambio 41(7):738-750. doi:10.1007/s13280-012-0292-3

Purnamasari RS (2010) Dynamics of small-scale deforestation in Indonesia: examining the effects of poverty and socio-economic development. Paper presented at the XIII World Forestry Congress, Rome

Ratnasari (2013, Juni 2013). Pengelolaan DAS Berbasis Masyarakat. Buletin RMI 10-11

Rudel TK, Defries R, Asner GP, Laurance WF (2009) Changing drivers of deforestation and new opportunities for conservation. Conserv Biol 23(6):1396-1405. doi:10.1111/j.1523-1739.2009. 01332.x

Rudel TK, Schneider L, Uriarte M (2010) Forest transitions: an introduction. Land Use Policy 27(2):95-97. doi:10.1016/j.land usepol.2009.09.021

Sandewall M, Nilsson NE (2001) The area production model: a tool and concept for sustainable land-use and forest-resource management. J Environ Manag 62(4):415-427. doi:10.1006/jema. 2001.0450

Sasaoka M, Laumonier Y (2012) Suitability of local resource management practices based on supernatural enforcement mechanisms in the local social-cultural context. Ecol Soc. doi:10.5751/ES-05124-170406

Sawathvong S (2004) Experiences from developing an integrated land-use planning approach for protected areas in the Lao PDR. For Policy Econ 6(6):553-566. doi:10.1016/S1389-9341(03) 00005-4 
Seidenberg C, Mertz O, Kias MB (2003) Fallow, labour and livelihood in shifting cultivation: implications for deforestation in northern Lao PDR. Dan J Geogr 103(2):71-80

Shearman PL, Ash J, Mackey B, Bryan JE, Lokes B (2009) Forest conversion and degradation in Papua New Guinea 1972-2002. Biotropica 41(3):379-390. doi:10.1111/j.1744-7429.2009.00495.x

Suhari I (2015) Perbaikan Statistik Beras. 29 Mei 2015. https:// indonesiana.tempo.co/read/41871/2015/05/29/iswadi.didi/perbai kan-statistik-beras

Susana, Ochoa-Gaona (2011) Traditional land-use systems and patterns of forest fragmentation in the highlands of Chiapas, Mexico. Environ Manag 27(4):571-586

Tachibana T, Nguyen TM, Otsuka K (2001) Agricultural Intensification versus extensification: a case study of deforestation in the Northern-Hill Region of Vietnam. J Environ Econ Manag 41(1):44-69. doi:10.1006/jeem.1998.1131

Tomich TP, van Noordwjik M, Budidarsono S, Gillison AN, Kusumanto T, Murdiyarso D, Stolle F, Fagi AM (2001) Agricultural intensification, deforestation, and the environment: assessing tradeoffs in Sumatra, Indonesia. Tradeoffs or synergies? Agricultural intensification, economic development, and the environment. CAB International, Wallingford, pp 221-244

Tropenbos International Indonesia (2006) Penilaian Ekonomi Sumberdaya Hutan Lindung Gunung Lumut, Kabupaten Paser, Kalimantan Timur (vol TE-06/TBI Indonesia/05-I). Tropenbos International Indonesia dan Greenomics Indonesia, Bogor

Verburg PH, Rounsevell MDA, Veldkamp A (2006) Scenario-based studies of future land use in Europe. Agric Ecosyst Environ 114(1):1-6. doi:10.1016/j.agee.2005.11.023
Wangpakapattanawong P, Kavinchan N, Vaidhayakarn C, SchmidtVogt D, Elliott S (2010) Fallow to forest: applying indigenous and scientific knowledge of swidden cultivation to tropical forest restoration. For Ecol Manag 260(8):1399-1406. doi:10.1016/j. foreco.2010.07.042

Wätzold F, Dreschsler M, Amstrong CW, Baumgärtner S, Grim V, Huth A, Wissel C (2006) Ecological-economic modeling for biodiversity management: potential, pitfalls, and prospects. Conserv Biol 20(4):1034-1041. doi:10.1111/j.1523-1739.2006. 00353.x

Wijaya T (2014). Indonesia Darurat Masyarakat Adat. Kenapa? http:// www.mongabay.co.id/2014/10/01/indonesia-darurat-masyara kat-adat-kenapa/. Cited 31 Maret 2015

Wollenberg E, Edmunds D, Buck L (2000) Anticipating change: scenarios as a tool for adaptive forest management: a guide. CIFOR, Bogor

Xiao YQ, Wei LJ, Zhou RJ (2001) Simulating deforestation of Nepal by area production model. J For Res 12(1):47-50. doi:10.1007/ bf02856800

Yanuariadi T (1999) Sustainable land allocation: GIS-based decision support for industrial forest plantation development in Indonesia. (PhD Dissertation), Wageningen, Enschede, The Netherlands. (ITC Publication Series, No. 71 (Dissertation No. 59))

Yasmi Y, Kelley L, Enters T (2010) Conflict over forests and land in Asia, Impact, causes and management. The Centre for People and Forests, RECOFTC, Bangkok, p 22 